Review

\title{
Emerging Evidence of Thresholds for Beneficial Effects from Vitamin D Supplementation
}

\author{
Robert Scragg \\ School of Population Health, University of Auckland, Private Bag 92019, Auckland 1142, New Zealand; \\ r.scragg@auckland.ac.nz; Tel.: +64-9-923-6336
}

Received: 15 March 2018; Accepted: 30 April 2018; Published: 3 May 2018

\begin{abstract}
Publications from clinical trials of vitamin D supplementation have increased substantially over the last 15 years. Yet, despite the growing number of randomized controlled trials, meta-analyses of these studies have drawn inconsistent conclusions. Many meta-analyses assume that vitamin D is a pharmacological agent, and give scant consideration of it being a nutrient. This limits their potential to detect beneficial effects in participants with vitamin D deficiency. An increasing body of evidence from both observational studies and clinical trials supports the presence of thresholds in vitamin $\mathrm{D}$ status below which disease risk increases and vitamin supplementation has beneficial effects. Future supplementation trials which seek to replicate these findings should recruit sufficient numbers of participants with low vitamin D levels, and not give low-dose vitamin D to the placebo group. If the presence of vitamin D thresholds for beneficial effects is confirmed, this would strengthen the need for vitamin $\mathrm{D}$ fortification of foods.
\end{abstract}

Keywords: dose-response; randomized controlled trials; thresholds; vitamin D supplementation

\section{Introduction}

The focus of vitamin $\mathrm{D}$ research in recent years has turned to the findings from randomized controlled trials (RCTs) of vitamin D supplementation. Figure 1 shows the more than 15 -fold increase over the last 15 years (2003-2017) in the number of publications in PubMed with the term 'vitamin D supplementation' in their title. This is much higher than the 5-fold increase for all vitamin D publications. Numbers of publications from vitamin D supplementation trials are expected to continue to grow, based on the $>100$ vitamin D RCTs currently in the pipeline and registered at ClinicalTrials.gov. In addition, the main findings from several current megatrials, including the US VITAL study [1], the Australian D-Health study [2], and the New Zealand ViDA study [3], are expected to be published over the next 3-4 years [4]. The results from these trials are likely to be influential in deciding whether or not vitamin D supplementation protects against common chronic or acute diseases.

In the meantime, guidelines on the use of vitamin D supplementation have relied on meta-analyses which typically combine the published results of small trials to increase the statistical power of detecting any beneficial effects from vitamin $\mathrm{D}$. The results of these meta-analyses have been inconsistent, with some reporting beneficial effects from vitamin D supplementation [5-8], and others reporting null effects [9-11]. Above these sit the so-called umbrella reviews, which are qualitative reviews of the meta-analyses, and which generally have concluded that vitamin D supplementation has no beneficial effects $[12,13]$. However, a recent umbrella review did conclude that most RCTs have been carried out in populations that are not vitamin D deficient and, because of this, possible beneficial effects from vitamin D supplementation cannot be excluded [14]. 


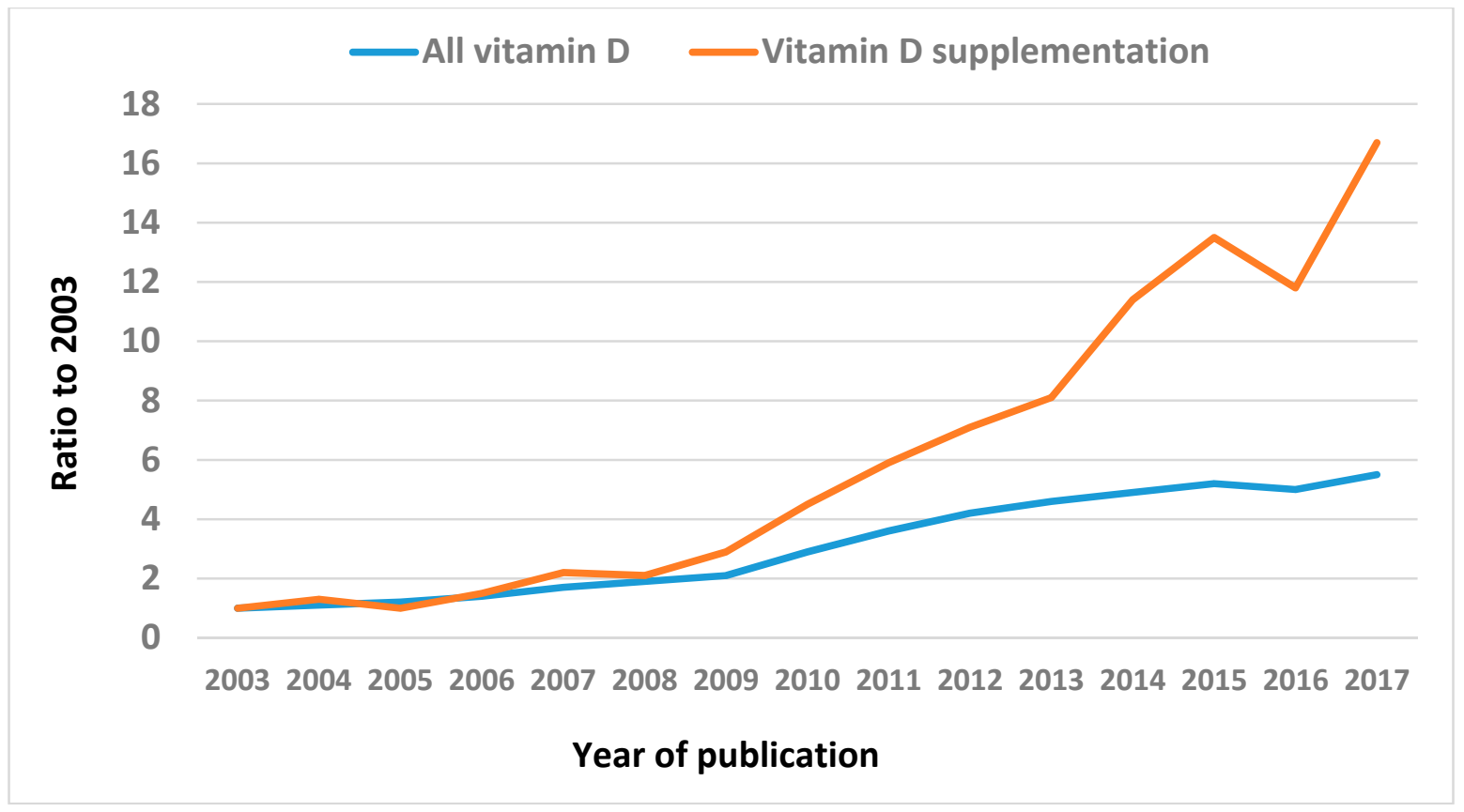

Figure 1. Ratio of number of annual publications (compared to 2003) with vitamin D in the title (all vitamin D), and with vitamin D supplementation or supplement(s) in the title (Pubmed: https:/ / www.ncbi.nlm.nih.gov/pubmed/).

While the major source of vitamin $\mathrm{D}$ is endogenous synthesis from sun exposure, a substantial proportion also comes from diet [15]. A common failing of many meta-analyses is that they assume that vitamin $\mathrm{D}$ is a pharmacological agent, and give scant consideration to it being a nutrient that can be ingested from food or as a supplement. The implications for the design of clinical trials (from vitamin D being a nutrient) were clearly described by Robert Heaney in an important manuscript published in 2014 [16]. Responses to drugs and nutrients, whether they be biochemical, physiological, or pharmacological, follow a sigmoid curve, with little change in the intended effect of the drug or nutrient at low intake levels until a critical point is reached where the effect increases rapidly in response to increased dose of the drug or nutrient, before plateauing out at higher doses. For most drugs, the intended effect extends over about three orders of magnitude of intake (or a thousandfold), and testing the effect of drug doses typically takes place in the midregion of the sigmoid curve where the line is straight and rapidly rising, resulting in effects that are usually linear. For nutrients, the intended effect usually extends over only one order of magnitude of intake (around 10-20-fold). For example, the usual measure of vitamin D status-circulating 25-hydroxyvitamin D $(25(\mathrm{OH}) \mathrm{D})$ concentration-typically ranges from around $25 \mathrm{nmol} / \mathrm{L}$ up to $225 \mathrm{nmol} / \mathrm{L}$, and vitamin D intake itself ranges from about 100 international units(IU) per day from diet up to about 2000 IU per day from supplements. Thus, determining the level of circulating $25(\mathrm{OH}) \mathrm{D}$ where any benefit starts to increase upwards along the sigmoid curve is necessary if they are to be detected.

Applying this knowledge to a recent clinical trial illustrates how the interpretation of the results can change. The example study found that high-dose vitamin D supplementation (2000 IU/day) did not reduce the number of upper respiratory tract infections compared with low-dose vitamin $D$ (400 IU/day) in Canadian children during winter, leading to the conclusion that routine use of vitamin D supplementation does not prevent these infections [17]. At baseline (September-November), the mean 25(OH)D was $90 \mathrm{nmol} / \mathrm{L}$ in the high vitamin D dose arm and $92 \mathrm{nmol} / \mathrm{L}$ in the low-dose arm. The standard deviation of about $30 \mathrm{nmol} / \mathrm{L}$ indicates that only 5-10 children in each arm were likely to have had baseline $25(\mathrm{OH}) \mathrm{D}$ concentrations of $<25 \mathrm{nmol} / \mathrm{L}$ - the level where beneficial effects were detected in a recent meta-analysis of RCTs of vitamin D supplementation and acute respiratory tract 
infection [18]. The follow-up mean 25(OHD) of $92 \mathrm{nmol} / \mathrm{L}$ in the low-dose vitamin D group, during April-May at the start of the seasonal Spring increase in vitamin D levels, also indicates that only a very small number of children would have had $25(\mathrm{OH}) \mathrm{D}$ concentrations of $<25 \mathrm{nmol} / \mathrm{L}$ during the winter months. Thus, an alternative explanation for the null findings in the Canadian study-findings which imply that vitamin D supplementation is not beneficial against upper respiratory infection-is that very few of the children had vitamin D levels below the threshold to see a benefit from vitamin D supplementation. As such, the Canadian study cannot be considered a proper test of the vitamin D hypothesis, as acknowledged by the authors of this study [19].

A previous review summarized the literature up to 2013 and concluded that the thresholds for beneficial vitamin D status could range from 25(OH)D of $25 \mathrm{nmol} / \mathrm{L}$ for bone disease up to $100 \mathrm{nmol} / \mathrm{L}$ for cancer [20]. Since then, results from a number of observational and interventional studies have been published; these are discussed below.

\section{Observational Studies}

Meta-analyses of cohort studies have provided some evidence of the location of possible thresholds along the $25(\mathrm{OH}) \mathrm{D}$ distribution, below which disease risk increases and benefits from vitamin D supplementation could potentially occur.

A meta-analysis of 32 cohort studies reported a nonlinear association between serum $25(\mathrm{OH}) \mathrm{D}$ and the hazard ratio (HR) for all-cause mortality, with an increase in the HR starting in the $25(\mathrm{OH}) \mathrm{D}$ range of 75-100 nmol/L, becoming significant in the range of 50 to $74 \mathrm{nmol} / \mathrm{L}$, and increasing to a maximum of 1.9 for people with $25(\mathrm{OH}) \mathrm{D}<25 \mathrm{nmol} / \mathrm{L}$ [21]. A subsequent meta-analysis of individual participant data (IPD) from seven cohorts with 26,916 participants also found a nonlinear association between $25(\mathrm{OH}) \mathrm{D}$ concentrations and the HR for all-cause mortality: the HR was unchanged over the range of 50-125 nmol/L, and increased substantially below $40 \mathrm{nmol} / \mathrm{L}$ as $25(\mathrm{OH}) \mathrm{D}$ decreased, up to about 2.8 for people with 25(OH)D of $<10 \mathrm{nmol} / \mathrm{L}$ [22]. Another IPD analysis of 26,018 participants from 8 cohort studies also found curvilinear associations (without any clear threshold) between baseline $25(\mathrm{OH}) \mathrm{D}$ concentration and risk of all-cause mortality and cardiovascular mortality [23]. A meta-analysis of 19 cohorts with 65,994 participants found that the risk of cardiovascular disease increased linearly for decreasing circulating 25(OH)D below $60 \mathrm{nmol} / \mathrm{L}$ but was unchanged above this value [24].

In contrast, cohort study meta-analyses have not detected nonlinear associations for diabetes [25] and colorectal cancer [26], although a decreasing risk of breast cancer above a 25(OH)D threshold of $67 \mathrm{nmol} / \mathrm{L}$ has been observed in postmenopausal (but not premenopausal) women [27]. In addition, a recent large Japanese nested case control study observed a step-down in the hazard ratio of $19 \%$ for incidence of all cancer when going from the lowest $25(\mathrm{OH}) \mathrm{D}$ quartile to the second; this remained unchanged in higher quartiles, suggesting a threshold effect at about 40-45 nmol/L [28].

Overall, meta-analyses of cohort studies suggest there is a threshold effect of vitamin D status on the risk of some chronic diseases, particularly for all-cause mortality and cardiovascular disease, at circulating 25(OH)D concentrations in the range of 40-75 nmol/L. This broad range for thresholds reported in observational studies could reflect differences in the quality of $25(\mathrm{OH}) \mathrm{D}$ assays, with some reading high and others low, thus making the actual cut-point unclear [29].

\section{Interventional Studies}

Evidence is starting to accumulate from clinical trials of threshold effects from vitamin D supplementation for preventing several clinical and physiological outcomes. These reports are a mixture of meta-analyses and individual RCTs, with several published in the last year (Table 1).

\subsection{Meta-Analyses}

The earliest is a Cochrane meta-analysis which found that vitamin D supplementation, compared with placebo, reduced the risk of falls in four studies that selected people with lower vitamin D 
levels [30]. The four studies had cut-points of $<30,<50,<78$, and $<60 \mathrm{nmol} / \mathrm{L}$ [31-34]. The 30\% reduction in the risk of falls in these studies (risk ratio $=0.70 ; 95 \%$ confidence interval (CI): $0.56-0.87$ ) was significantly lower than in the other nine studies that did not select participants based on vitamin D status (risk ratio $=1.00 ; 95 \%$ CI: 0.93-1.07; $P_{\text {interaction }}<0.01$ ).

An IPD meta-analysis of 25 trials found that vitamin D supplementation, compared with placebo, significantly reduced the odds of having an acute respiratory infection in participants with baseline $25(\mathrm{OH}) \mathrm{D}$ levels of $<25 \mathrm{nmol} / \mathrm{L}$ (odds ratio $=0.58 ; 95 \% \mathrm{CI}: 0.40-0.82$ ), equivalent to a $26 \%$ reduction in risk; this was more than in participants with levels $\geq 25 \mathrm{nmol} / \mathrm{L}$ (odds ratio $=0.89 ; 95 \%$ CI: 0.77-1.04; $\left.P_{\text {interaction }}=0.01\right)$ where the risk reduction was a nonsignificant $6 \%$ [18].

A further IPD meta-analysis of seven trials, led by the same group [35], reported that vitamin D supplementation, when compared with placebo, reduced the incidence rate of exacerbations in asthma patients who had baseline $25(\mathrm{OH}) \mathrm{D}$ concentrations of $<25 \mathrm{nmol} / \mathrm{L}$ by $67 \%$ (rate ratio $=0.33 ; 95 \%$ CI: $0.11-0.98$ ), but not in those with baseline levels $\geq 25 \mathrm{nmol} / \mathrm{L}$ (rate ratio $=0.77 ; 95 \%$ CI: 0.58-1.03). The $p$-value for the interaction was not significant, and the rate ratio combining all participants was significant (rate ratio $=0.74,95 \% \mathrm{CI}$ : 0.56-0.97). However, given the relatively small number of participants $(n=856)$, more studies are required to determine whether the protective effect of vitamin D supplementation against asthma exacerbations varies with vitamin D status.

\subsection{Individual Trials}

Recent results from individual studies also provide evidence for the effect of vitamin D supplementation being greater in people with vitamin $\mathrm{D}$ deficiency.

A trial in patients with chronic obstructive pulmonary disease in Belgium found that vitamin D supplementation given orally as bolus 100,000 IU doses every 4 weeks for one year reduced the incidence rate of exacerbations from this condition by $43 \%$ in patients with baseline $25(\mathrm{OH}) \mathrm{D}$ concentrations of $<25 \mathrm{nmol} / \mathrm{L}$ - a greater reduction than in those with higher $25(\mathrm{OH}) \mathrm{D}$ levels $\left(P_{\text {interaction }}=0.027\right)[36]$.

A trial from Austria found that vitamin D supplementation-a 540,000 IU bolus followed by 90,000 IU monthly for 6 months given orally or by nasogastric tube-reduced hospital mortality in patients admitted to intensive care units by $38 \%$ after 6 months in those who had baseline $25(\mathrm{OH}) \mathrm{D}$ levels of $\leq 30 \mathrm{nmol} / \mathrm{L}(\mathrm{HR}=0.56 ; 95 \% \mathrm{CI}: 0.35-0.90)$ but not in those above this level $(\mathrm{HR}=1.12 ; 95 \%$ CI: $\left.0.72-1.77 ; P_{\text {interaction }}=0.04\right)$ [37].

Findings from the recently completed Vitamin D Assessment (ViDA) study carried out in New Zealand, which gave an oral bolus vitamin D dose of 100,000 IU/month [3], show significant interactions in the effect of vitamin D supplementation on some outcomes with regard to baseline $25(\mathrm{OH}) \mathrm{D}$ level. There was greater attenuation of bone mineral density loss in the spine and femoral neck after 2 years in people with $25(\mathrm{OH}) \mathrm{D} \leq 30 \mathrm{nmol} / \mathrm{L}$ compared with in those above this level $\left(P_{\text {interaction }}=0.04\right)$ [38]. The reduced decline in bone mineral density ( $2 \%$ over 2 years) from vitamin $\mathrm{D}$ was small relative to other more powerful anti-osteoporotic drugs, but vitamin D supplementation may be important if targeted at populations known to have low 25(OH)D levels such as the elderly living in institutions [39]. The beneficial effect in participants with low $25(\mathrm{OH}) \mathrm{D}$ levels is consistent with the increased bone mineral density seen in infants born in winter to mothers given vitamin $\mathrm{D}$ supplements during pregnancy, but not in births in other seasons [40]. 
Table 1. Summary of meta-analyses of randomized controlled trials of vitamin D supplementation and individual trials which have shown a beneficial effect in participants with low vitamin D status.

\begin{tabular}{|c|c|c|c|c|c|}
\hline Study & Design & Outcome & $\begin{array}{l}\text { Baseline } 25(\mathrm{OH}) \mathrm{D} \text { Subgroup: No. } \\
\text { Vitamin D/No. Placebo }\end{array}$ & $\begin{array}{l}\text { Results for Vitamin D Subgroups } \\
\text { Measure of Effect }(95 \% \text { CI) }\end{array}$ & $p$-Value for Interaction \\
\hline \multicolumn{6}{|c|}{ Meta-Analyses } \\
\hline Gillespie 2012 [30] & $\begin{array}{l}\text { Meta-analysis of } 13 \text { RCTs } \\
\text { of people living in the } \\
\text { community }\end{array}$ & Falls & $\begin{array}{l}\text { Study selected for low vitamin D: } \\
\text { Yes: } 405 / 399 \\
\text { No: } 12,636 / 13,307\end{array}$ & $\begin{array}{l}\mathrm{RR}=0.70(0.56,0.87) \\
\mathrm{RR}=1.00(0.93,1.07)\end{array}$ & $<0.01$ \\
\hline Martineau 2017 [18] & $\begin{array}{l}\text { IPD meta-analysis of } 25 \\
\text { RCTs of people from a } \\
\text { range of settings }\end{array}$ & $\begin{array}{l}\text { Acute respiratory } \\
\text { infection }\end{array}$ & $\begin{array}{l}25(\mathrm{OH}) \mathrm{D}<25 \mathrm{nmol} / \mathrm{L}: 289 / 249 \\
25(\mathrm{OH}) \mathrm{D} \geq 25 \mathrm{nmol} / \mathrm{L}: 1995 / 1639\end{array}$ & $\begin{array}{l}\mathrm{OR}=0.58(0.40 \text { to } 0.82) \\
\mathrm{OR}=0.89(0.77 \text { to } 1.04)\end{array}$ & 0.01 \\
\hline Jolliffe 2017 [35] & $\begin{array}{l}\text { IPD meta-analysis of } 7 \\
\text { RCTs of asthma patients }\end{array}$ & Asthma exacerbations & $\begin{array}{l}<25 \mathrm{nmol} / \mathrm{L}: 92 \text { patients in } 3 \text { trials } \\
\geq 25 \mathrm{nmol} / \mathrm{L}: 764 \text { patients in } 6 \text { trials }\end{array}$ & $\begin{array}{l}\mathrm{IRR}=0.33(0.11-0.98) \\
\mathrm{IRR}=0.77(0.58-1.03)\end{array}$ & 0.25 \\
\hline \multicolumn{6}{|c|}{ Individual Trials } \\
\hline Lehouck 2012 [36] & $\begin{array}{l}\text { Single RCT of COPD } \\
\text { patients }\end{array}$ & COPD exacerbations & $\begin{array}{l}25(\mathrm{OH}) \mathrm{D}<25 \mathrm{nmol} / \mathrm{L}: 15 / 15 \\
25(\mathrm{OH}) \mathrm{D} \geq 25 \mathrm{nmol} / \mathrm{L}: 76 / 76\end{array}$ & $\begin{array}{l}\text { Lower IRR }=0.57(0.33 \text { to } 0.98) \text { in } \\
\text { patients with } 25(\mathrm{OH}) \mathrm{D}<25 \mathrm{vs} \text {. } \\
\geq 25 \mathrm{nmol} / \mathrm{L} \text {. }\end{array}$ & 0.027 \\
\hline Amrein 2014 [37] & $\begin{array}{l}\text { Single RCT of patients } \\
\text { admitted to intensive } \\
\text { care units }\end{array}$ & Mortality (in hospital) & $\begin{array}{l}25(\mathrm{OH}) \mathrm{D} \leq 30 \mathrm{nmol} / \mathrm{L}: 102 / 98 \\
25(\mathrm{OH}) \mathrm{D}>30 \mathrm{nmol} / \mathrm{L}: 136 / 139\end{array}$ & $\begin{array}{l}\mathrm{HR}=0.56(0.35-0.90) \\
\mathrm{HR}=1.12(0.72-1.77)\end{array}$ & 0.04 \\
\hline Reid 2017 [38] & $\begin{array}{l}\text { Single } \mathrm{RCT} \text { of community } \\
\text { resident adults }\end{array}$ & $\begin{array}{l}\text { Bone mineral density } \\
\text { (change over } 2 \text { years) }\end{array}$ & $\begin{array}{l}25(\mathrm{OH}) \mathrm{D} \leq 30 \mathrm{nmol} / \mathrm{L}: 25 / 21 \\
25(\mathrm{OH}) \mathrm{D}>30 \mathrm{nmol} / \mathrm{L}: 179 / 185\end{array}$ & $\begin{array}{l}\text { Greater attenuation of spine and } \\
\text { femoral neck BMD loss in people } \\
\text { with } 25(\mathrm{OH}) \mathrm{D} \leq 30 \mathrm{vs} \text {. } \\
>30 \mathrm{nmol} / \mathrm{L} \text {. }\end{array}$ & 0.04 \\
\hline Sluyter 2017 [41] & $\begin{array}{l}\text { Single } \mathrm{RCT} \text { of community } \\
\text { resident adults }\end{array}$ & $\begin{array}{l}\text { Arterial function (change } \\
\text { over } 1 \text { year) }\end{array}$ & $\begin{array}{l}25(\mathrm{OH}) \mathrm{D}<50 \mathrm{nmol} / \mathrm{L}: 71 / 79 \\
25(\mathrm{OH}) \mathrm{D} \geq 50 \mathrm{nmol} / \mathrm{L}: 122 / 108\end{array}$ & $\begin{array}{l}\text { Greater reduction in several arterial } \\
\text { waveform parameters (e.g., } \\
\text { augmentation index, pulse wave } \\
\text { velocity) in people with } 25(\mathrm{OH}) \mathrm{D}< \\
50 \mathrm{vs} . \geq 50 \mathrm{nmol} / \mathrm{L} \text {. }\end{array}$ & $<0.05$ \\
\hline Sluyter 2018 [42] & $\begin{array}{l}\text { Single } \mathrm{RCT} \text { of community } \\
\text { resident adults }\end{array}$ & $\begin{array}{l}\text { Lung function (change } \\
\text { over } 1 \text { year) }\end{array}$ & $\begin{array}{l}\text { Ever smoked tobacco: } \\
25(\mathrm{OH}) \mathrm{D}<50 \mathrm{nmol} / \mathrm{L}: 26 / 28 \\
25(\mathrm{OH}) \mathrm{D} \geq 50 \mathrm{nmol} / \mathrm{L}: 78 / 85\end{array}$ & $\begin{array}{l}\text { Greater increase in } \mathrm{FEV}_{1} \text { in ever } \\
\text { smokers with } 25(\mathrm{OH}) \mathrm{D}<50 \text { vs. } \\
\geq 50 \mathrm{nmol} / \mathrm{L} \text {. }\end{array}$ & 0.048 \\
\hline
\end{tabular}

$\mathrm{BMD}=$ bone mineral density $\mathrm{CI}$ = confidence interval; $\mathrm{COPD}=$ chronic obstructive pulmonary disease; $\mathrm{FEV}_{1}=$ forced expiratory volume in 1 second; $\mathrm{HR}=$ hazard ratio; $\mathrm{IPD}=$ individual patient data; $\mathrm{IRR}=$ incidence rate ratio; $\mathrm{OR}=$ odds ratio; $\mathrm{RCT}=$ randomized controlled trial; $\mathrm{RR}=$ risk ratio. 
Interactions in the effect of vitamin D supplementation by baseline vitamin D status were seen also for several measures of arterial function in the ViDA study [41]. Greater reductions in arterial waveform parameters, such as augmentation index and pulse wave velocity, were seen after 12 months of supplementation in participants with baseline $25(\mathrm{OH}) \mathrm{D}<50 \mathrm{nmol} / \mathrm{L}$ compared with those above this cut-point (all $P_{\text {interaction }}<0.05$ ). The clinical significance of these findings is unclear at the moment until further research quantifies the role of these parameters in predicting cardiovascular disease. In addition, vitamin D supplementation for one year (compared with placebo) increased forced expiratory volume in $1 \mathrm{~s}\left(\mathrm{FEV}_{1}\right)$, measured by spirometry, more in participants who had ever smoked tobacco and had 25(OH)D levels of $<50 \mathrm{nmol} / \mathrm{L}$ (by $109 \mathrm{~mL}$ or $5 \%$ ) than in those who had ever smoked and had higher vitamin D levels $\left(P_{\text {interaction }}=0.048\right)$ [42]. Changes in $\mathrm{FEV}_{1}$ of $>100 \mathrm{~mL}$ are clinically significant [43].

Overall, these trials reported threshold effects from vitamin D supplementation that are beneficial for people with $25(\mathrm{OH}) \mathrm{D}$ concentrations of $<25-30 \mathrm{nmol} / \mathrm{L}$, and which may extend up to $50 \mathrm{nmol} / \mathrm{L}$ for measures such as arterial function and lung function. Their results indicate that if future research aims to determine with certainty whether vitamin D supplements are beneficial in people with vitamin $\mathrm{D}$ deficiency, researchers need to recruit sufficient participants with low 25(OH)D concentrations, and not give low-dose vitamin D to the control arm, as was done in the Canadian winter study [17]. This is because there is an inverse association between baseline $25(\mathrm{OH}) \mathrm{D}$ levels and the increase in $25(\mathrm{OH}) \mathrm{D}$ response to supplementation [44,45], such that even low vitamin D doses, when given to vitamin-D-deficient people, have the potential to increase $25(\mathrm{OH}) \mathrm{D}$ levels above a deficiency threshold of $25 \mathrm{nmol} / \mathrm{L}$.

The need for future supplementation trials to recruit people who are vitamin D deficient, and not give any dose of vitamin D supplement to the placebo arm, does raise serious practical and ethical issues. One strategy around this is to recruit participants from populations likely to have low 25(OH)D concentrations (e.g., those who are older, institutionalized, or with increased skin pigmentation), but not measure baseline $25(\mathrm{OH}) \mathrm{D}$ level. By not identifying those who are deficient at baseline, the ethical requirement to provide vitamin D supplements is avoided. Instead, blood samples can be collected at baseline and stored for later measurement of $25(\mathrm{OH}) \mathrm{D}$ so that vitamin-D-deficient participants can be identified after follow-up has been completed. This strategy has been used by some of the current mega-trials [1-3] and has been justified on the basis of the current state of equipoise regarding the lack of knowledge about the nonskeletal effects of vitamin $D$. The alternative-of excluding vitamin-D-deficient people or giving low vitamin D doses to the placebo group-is to continue to fail to detect possible beneficial effects from vitamin D supplementation as reported in some recent studies $[17,46]$.

Results from further RCTs may clarify whether the threshold for beneficial effects from vitamin D supplementation varies between different disease outcomes, as previously proposed [20]. Such trials will need to ensure they use $25(\mathrm{OH}) \mathrm{D}$ assays that are standardized to current gold standard reference methods to avoid confusion about the level of any detected thresholds [29].

\section{Daily versus Intermittent Vitamin D Supplementation}

In contrast, beneficial effects from vitamin D supplementation have not been observed for some outcomes in vitamin-D-deficient people. For example, the ViDA study did not see a reduction in the risk of cardiovascular disease, falls, or fractures in the vitamin D arm among participants with $25(\mathrm{OH}) \mathrm{D}$ concentrations of $<50 \mathrm{nmo} / \mathrm{L}[47,48]$. A possible explanation for the lack of vitamin D effect against these outcomes in vitamin-D-deficient people was the use of a monthly bolus dose of vitamin $\mathrm{D}$ in the ViDA study. Even though a sufficiently high vitamin D dose was given in the ViDA study to increase mean 25(OH)D levels in the treatment arm above $100 \mathrm{nmol} / \mathrm{L}$, it is possible that the short half-life of vitamin $\mathrm{D}$, which is more easily transported into cells than $25(\mathrm{OH}) \mathrm{D}$, resulted in short-lived peaks in intracellular vitamin D followed by longer periods of insufficient vitamin D [49,50]. 
Some evidence in support for this comes from the meta-analysis of respiratory infection which found that daily or weekly vitamin D supplementation resulted in a stronger reduction in the odds of respiratory infection than bolus dosing $\left(P_{\text {interaction }}=0.05\right)$ [18]. However, for several outcomes, such as those seen in the ViDA study for bone density and arterial and lung function $[38,41,42]$, and in the trials of COPD exacerbations [36] and mortality in patients admitted to intensive care units [37], the evidence shows that bolus dosing is beneficial among people with low vitamin D levels. Further evidence comparing the effects of daily versus bolus dosing will emerge within the next 2-3 years from comparisons between the VITAL study, which gave daily (2000 IU) dosing [1], and the D-Health study, which gave the same size dose but monthly (60,000 IU) [2]. The measurement of circulating cholecalciferol has the potential to clarify any differences in effect between daily and bolus dosing [50].

\section{Public Health Implications}

If evidence continues to accumulate of beneficial effects from vitamin D supplementation that are confined to, or maximal in, people with low 25(OH)D levels, this will have implications for public health strategies for preventing vitamin D deficiency. Traditionally, the two approaches for prevention have been the high-risk approach and the population approach [51]. The former would involve screening people for vitamin D deficiency using the $25(\mathrm{OH}) \mathrm{D}$ test, and then providing vitamin D supplements to those who are deficient, with the 25(OH)D threshold for deficiency determined by the ongoing research. Such an approach would have a high cost-benefit ratio if the 25(OH)D threshold was closer to $25 \mathrm{nmol} / \mathrm{L}$ than to $50 \mathrm{nmol} / \mathrm{L}$, as only a small proportion of the population would benefit from vitamin D supplements, while a much larger proportion would need to be screened to detect those who are deficient.

The cost-benefit ratio would decline for population groups with low $25(\mathrm{OH}) \mathrm{D}$ levels, such as South Asians [52], in whom the prevalence of vitamin D deficiency is high and the number needed to screen to detect one case of vitamin D deficiency would be low. In such communities, a population prevention strategy of vitamin D supplementation without any $25(\mathrm{OH}) \mathrm{D}$ screening could be considered, as vitamin $\mathrm{D}$ is very cheap and has no side effects of clinical significance when given in recommended doses $[53,54]$.

A more effective approach to preventing vitamin D deficiency when it occurs in only a small proportion of the community would be the population approach of vitamin $\mathrm{D}$ fortification, as it avoids the large costs from $25(\mathrm{OH}) \mathrm{D}$ screening of the whole population to detect and supplement the minority with vitamin $\mathrm{D}$ deficiency. Adding small amounts of vitamin $\mathrm{D}$ to commonly eaten foods, at low cost, would shift the distribution of $25(\mathrm{OH}) \mathrm{D}$ in the whole population to the right and minimize the proportion who are vitamin D deficient [55]. Modelling based on national food consumption data and the level of achievable vitamin $\mathrm{D}$ fortification would need to be carried out for individual countries to determine the effectiveness of this approach in shifting the $25(\mathrm{OH}) \mathrm{D}$ distribution to the right. Recent analyses indicate that a dietary vitamin D intake of $26 \mu \mathrm{g} /$ day would be required to ensure that $97.5 \%$ of adults had $25(\mathrm{OH}) \mathrm{D}$ levels above $50 \mathrm{nmol} / \mathrm{L}$ [56]; this is unlikely to be achieved with fortification by itself and probably requires some vitamin D supplementation. Moreover, the daily requirement for vitamin $D$ varies between sections of the population, being highest in older adults [57]. However, the need for such modelling research would increase if future RCTs confirm $25(\mathrm{OH}) \mathrm{D}$ thresholds for beneficial effects from vitamin D supplementation.

\section{Conclusions}

An increasing body of evidence from both observational studies and clinical trials supports the presence of thresholds in vitamin $\mathrm{D}$ status below which disease risk increases and vitamin supplementation has beneficial effects. Further trials are required to determine whether or not the findings summarized in Table 1 are false-positive results due to chance. Future supplementation trials which seek to replicate these findings should recruit sufficient numbers of participants with low 
vitamin D levels (all with $25(\mathrm{OH}) \mathrm{D}<50 \mathrm{nmol} / \mathrm{L}$, and a good proportion with $<25 \mathrm{nmol} / \mathrm{L}$ ), not give low-dose vitamin $\mathrm{D}$ to the placebo group, and include the measurement of circulating cholecalciferol (at least in a subgroup). If the presence of vitamin D thresholds for beneficial effects is confirmed, this would strengthen the need for vitamin $\mathrm{D}$ fortification of foods.

Acknowledgments: The ViDA study was funded by a grant (10/400) from the Health Research Council of New Zealand, and by funding from the Accident Compensation Corporation of New Zealand.

Conflicts of Interest: The author declares no conflict of interest. The funding sponsors had no role in the design of the study; in the collection, analyses, or interpretation of data; in the writing of the manuscript; or in the decision to publish the results.

\section{References}

1. Manson, J.E.; Bassuk, S.S.; Lee, I.M.; Cook, N.R.; Albert, M.A.; Gordon, D.; Zaharris, E.; Macfadyen, J.G.; Danielson, E.; Lin, J.; et al. The vitamin D and omega-3 trial (VITAL): Rationale and design of a large randomized controlled trial of vitamin $\mathrm{D}$ and marine omega-3 fatty acid supplements for the primary prevention of cancer and cardiovascular disease. Contemp. Clin. Trials 2012, 33, 159-171. [CrossRef] [PubMed]

2. Neale, R.E.; Armstrong, B.K.; Baxter, C.; Duarte Romero, B.; Ebeling, P.; English, D.R.; Kimlin, M.G.; McLeod, D.S.; O Connell, R.L.; van der Pols, J.C.; et al. The D-health trial: A randomized trial of vitamin D for prevention of mortality and cancer. Contemp. Clin. Trials 2016, 48, 83-90. [CrossRef] [PubMed]

3. Scragg, R.; Waayer, D.; Stewart, A.W.; Lawes, C.M.; Toop, L.; Murphy, J.; Khaw, K.T.; Camargo, C.A., Jr. The Vitamin D Assessment (ViDA) study: Design of a randomized controlled trial of vitamin D supplementation for the prevention of cardiovascular disease, acute respiratory infection, falls and non-vertebral fractures. J. Steroid Biochem. Mol. Biol. 2016, 164, 318-325. [CrossRef] [PubMed]

4. Meyer, H.E.; Holvik, K.; Lips, P. Should vitamin D supplements be recommended to prevent chronic diseases? BMJ 2015, 350, h321. [CrossRef] [PubMed]

5. Bjelakovic, G.; Gluud, L.L.; Nikolova, D.; Whitfield, K.; Krstic, G.; Wetterslev, J.; Gluud, C. Vitamin D supplementation for prevention of cancer in adults. Cochrane Database Syst. Rev. 2014, 6, CD007469. [CrossRef] [PubMed]

6. Bischoff-Ferrari, H.A.; Willett, W.C.; Wong, J.B.; Giovannucci, E.; Dietrich, T.; Dawson-Hughes, B. Fracture prevention with vitamin D supplementation: A meta-analysis of randomized controlled trials. JAMA 2005, 293, 2257-2264. [CrossRef] [PubMed]

7. Zheng, Y.; Zhu, J.; Zhou, M.; Cui, L.; Yao, W.; Liu, Y. Meta-analysis of long-term vitamin D supplementation on overall mortality. PLoS ONE 2013, 8, e82109. [CrossRef] [PubMed]

8. Roth, D.E.; Leung, M.; Mesfin, E.; Qamar, H.; Watterworth, J.; Papp, E. Vitamin D supplementation during pregnancy: State of the evidence from a systematic review of randomised trials. BMJ 2017, 359, j5237. [CrossRef] [PubMed]

9. Zheng, Y.T.; Cui, Q.Q.; Hong, Y.M.; Yao, W.G. A meta-analysis of high dose, intermittent vitamin D supplementation among older adults. PLoS ONE 2015, 10, e0115850. [CrossRef] [PubMed]

10. Bolland, M.J.; Grey, A.; Gamble, G.D.; Reid, I.R. The effect of vitamin D supplementation on skeletal, vascular, or cancer outcomes: A trial sequential meta-analysis. Lancet Diabetes Endocrinol. 2014, 2, 307-320. [CrossRef]

11. Bolland, M.J.; Grey, A.; Gamble, G.D.; Reid, I.R. Vitamin D supplementation and falls: A trial sequential meta-analysis. Lancet Diabetes Endocrinol. 2014, 2, 573-580. [CrossRef]

12. Theodoratou, E.; Tzoulaki, I.; Zgaga, L.; Ioannidis, J.P. Vitamin D and multiple health outcomes: Umbrella review of systematic reviews and meta-analyses of observational studies and randomised trials. BMJ 2014, 348, g2035. [CrossRef] [PubMed]

13. Autier, P.; Mullie, P.; Macacu, A.; Dragomir, M.; Boniol, M.; Coppens, K.; Pizot, C.; Boniol, M. Effect of vitamin D supplementation on non-skeletal disorders: A systematic review of meta-analyses and randomised trials. Lancet Diabetes Endocrinol. 2017, 5, 986-1004. [CrossRef]

14. Rejnmark, L.; Bislev, L.S.; Cashman, K.D.; Eiriksdottir, G.; Gaksch, M.; Grubler, M.; Grimnes, G.; Gudnason, V.; Lips, P.; Pilz, S.; et al. Non-skeletal health effects of vitamin D supplementation: A systematic review on findings from meta-analyses summarizing trial data. PLoS ONE 2017, 12, e0180512. [CrossRef] [PubMed] 
15. Heaney, R.P.; Armas, L.A.; French, C. All-source basal vitamin D inputs are greater than previously thought and cutaneous inputs are smaller. J. Nutr. 2013, 143, 571-575. [CrossRef] [PubMed]

16. Heaney, R.P. Guidelines for optimizing design and analysis of clinical studies of nutrient effects. Nutr. Rev. 2014, 72, 48-54. [CrossRef] [PubMed]

17. Aglipay, M.; Birken, C.S.; Parkin, P.C.; Loeb, M.B.; Thorpe, K.; Chen, Y.; Laupacis, A.; Mamdani, M.; Macarthur, C.; Hoch, J.S.; et al. Effect of high-dose vs. standard-dose wintertime vitamin D supplementation on viral upper respiratory tract infections in young healthy children. JAMA 2017, 318, 245-254. [CrossRef] [PubMed]

18. Martineau, A.R.; Jolliffe, D.A.; Hooper, R.L.; Greenberg, L.; Aloia, J.F.; Bergman, P.; Dubnov-Raz, G.; Esposito, S.; Ganmaa, D.; Ginde, A.A.; et al. Vitamin D supplementation to prevent acute respiratory tract infections: Systematic review and meta-analysis of individual participant data. BMJ 2017, 356, i6583. [CrossRef] [PubMed]

19. Aglipay, M.; Maguire, J.L. Vitamin D supplementation and upper respiratory tract infections in children-reply. JAMA 2017, 318, 2139-2140. [CrossRef] [PubMed]

20. Spedding, S.; Vanlint, S.; Morris, H.; Scragg, R. Does vitamin d sufficiency equate to a single serum 25-hydroxyvitamin D level or are different levels required for non-skeletal diseases? Nutrients 2013, 5, 5127-5139. [CrossRef] [PubMed]

21. Garland, C.F.; Kim, J.J.; Mohr, S.B.; Gorham, E.D.; Grant, W.B.; Giovannucci, E.L.; Baggerly, L.; Hofflich, H.; Ramsdell, J.W.; Zeng, K.; et al. Meta-analysis of all-cause mortality according to serum 25-hydroxyvitamin D. Am. J. Public Health 2014, 104, e43-e50. [CrossRef] [PubMed]

22. Gaksch, M.; Jorde, R.; Grimnes, G.; Joakimsen, R.; Schirmer, H.; Wilsgaard, T.; Mathiesen, E.B.; Njolstad, I.; Lochen, M.L.; Marz, W.; et al. Vitamin D and mortality: Individual participant data meta-analysis of standardized 25-hydroxyvitamin d in 26916 individuals from a European consortium. PLoS ONE 2017, 12, e0170791. [CrossRef] [PubMed]

23. Schottker, B.; Jorde, R.; Peasey, A.; Thorand, B.; Jansen, E.H.; Groot, L.; Streppel, M.; Gardiner, J.; Ordonez-Mena, J.M.; Perna, L.; et al. Vitamin D and mortality: Meta-analysis of individual participant data from a large consortium of cohort studies from Europe and the United States. BMJ 2014, 348, g3656. [CrossRef] [PubMed]

24. Wang, L.; Song, Y.; Manson, J.E.; Pilz, S.; Marz, W.; Michaelsson, K.; Lundqvist, A.; Jassal, S.K.; Barrett-Connor, E.; Zhang, C.; et al. Circulating 25-hydroxy-vitamin D and risk of cardiovascular disease: A meta-analysis of prospective studies. Circ. Cardiovasc. Qual. Outcomes 2012, 5, 819-829. [CrossRef] [PubMed]

25. Song, Y.; Wang, L.; Pittas, A.G.; Del Gobbo, L.C.; Zhang, C.; Manson, J.E.; Hu, F.B. Blood 25-hydroxy vitamin D levels and incident type 2 diabetes: A meta-analysis of prospective studies. Diabetes Care 2013, 36, 1422-1428. [CrossRef] [PubMed]

26. Ma, Y.; Zhang, P.; Wang, F.; Yang, J.; Liu, Z.; Qin, H. Association between vitamin D and risk of colorectal cancer: A systematic review of prospective studies. J. Clin. Oncol. 2011, 29, 3775-3782. [CrossRef] [PubMed]

27. Bauer, S.R.; Hankinson, S.E.; Bertone-Johnson, E.R.; Ding, E.L. Plasma vitamin D levels, menopause, and risk of breast cancer: Dose-response meta-analysis of prospective studies. Medicine (Baltimore) 2013, 92, 123-131. [CrossRef] [PubMed]

28. Budhathoki, S.; Hidaka, A.; Yamaji, T.; Sawada, N.; Tanaka-Mizuno, S.; Kuchiba, A.; Charvat, H.; Goto, A.; Kojima, S.; Sudo, N.; et al. Plasma 25-hydroxyvitamin D concentration and subsequent risk of total and site specific cancers in Japanese population: Large case-cohort study within Japan public health center-based prospective study cohort. BMJ 2018, 360, k671. [CrossRef] [PubMed]

29. Binkley, N.; Dawson-Hughes, B.; Durazo-Arvizu, R.; Thamm, M.; Tian, L.; Merkel, J.M.; Jones, J.C.; Carter, G.D.; Sempos, C.T. Vitamin D measurement standardization: The way out of the chaos. J. Steroid Biochem. Mol. Biol. 2017, 173, 117-121. [CrossRef] [PubMed]

30. Gillespie, L.D.; Robertson, M.C.; Gillespie, W.J.; Sherrington, C.; Gates, S.; Clemson, L.M.; Lamb, S.E. Interventions for preventing falls in older people living in the community. Cochrane Database Syst. Rev. 2012, 9, CD007146. [CrossRef] [PubMed]

31. Dhesi, J.K.; Jackson, S.H.; Bearne, L.M.; Moniz, C.; Hurley, M.V.; Swift, C.G.; Allain, T.J. Vitamin D supplementation improves neuromuscular function in older people who fall. Age Ageing 2004, 33, 589-595. [CrossRef] [PubMed] 
32. Pfeifer, M.; Begerow, B.; Minne, H.W.; Abrams, C.; Nachtigall, D.; Hansen, C. Effects of a short-term vitamin $\mathrm{D}$ and calcium supplementation on body sway and secondary hyperparathyroidism in elderly women. J. Bone Miner. Res. 2000, 15, 1113-1118. [CrossRef] [PubMed]

33. Pfeifer, M.; Begerow, B.; Minne, H.W.; Suppan, K.; Fahrleitner-Pammer, A.; Dobnig, H. Effects of a long-term vitamin $\mathrm{D}$ and calcium supplementation on falls and parameters of muscle function in community-dwelling older individuals. Osteoporos. Int. 2009, 20, 315-322. [CrossRef] [PubMed]

34. Prince, R.L.; Austin, N.; Devine, A.; Dick, I.M.; Bruce, D.; Zhu, K. Effects of ergocalciferol added to calcium on the risk of falls in elderly high-risk women. Arch. Intern. Med. 2008, 168, 103-108. [CrossRef] [PubMed]

35. Jolliffe, D.A.; Greenberg, L.; Hooper, R.L.; Griffiths, C.J.; Camargo, C.A., Jr.; Kerley, C.P.; Jensen, M.E.; Mauger, D.; Stelmach, I.; Urashima, M.; et al. Vitamin D supplementation to prevent asthma exacerbations: A systematic review and meta-analysis of individual participant data. Lancet Respir. Med. 2017, 5, 881-890. [CrossRef]

36. Lehouck, A.; Mathieu, C.; Carremans, C.; Baeke, F.; Verhaegen, J.; Van Eldere, J.; Decallonne, B.; Bouillon, R.; Decramer, M.; Janssens, W. High doses of vitamin D to reduce exacerbations in chronic obstructive pulmonary disease: A randomized trial. Ann. Intern. Med. 2012, 156, 105-114. [CrossRef] [PubMed]

37. Amrein, K.; Schnedl, C.; Holl, A.; Riedl, R.; Christopher, K.B.; Pachler, C.; Urbanic Purkart, T.; Waltensdorfer, A.; Munch, A.; Warnkross, H.; et al. Effect of high-dose vitamin D3 on hospital length of stay in critically ill patients with vitamin D deficiency: The VITDAL-ICU randomized clinical trial. JAMA 2014, 312, 1520-1530. [CrossRef] [PubMed]

38. Reid, I.R.; Horne, A.M.; Mihov, B.; Gamble, G.D.; Al-Abuwsi, F.; Singh, M.; Taylor, L.; Fenwick, S.; Camargo, C.A.; Stewart, A.W.; et al. Effect of monthly high-dose vitamin D on bone density in community-dwelling older adults substudy of a randomized controlled trial. J. Intern. Med. 2017, 282, 452-460. [CrossRef] [PubMed]

39. Bouillon, R. How much vitamin D is needed for healthy bones? J. Intern. Med. 2017, 282, 461-464. [CrossRef] [PubMed]

40. Cooper, C.; Harvey, N.C.; Bishop, N.J.; Kennedy, S.; Papageorghiou, A.T.; Schoenmakers, I.; Fraser, R.; Gandhi, S.V.; Carr, A.; D’Angelo, S.; et al. Maternal gestational vitamin D supplementation and offspring bone health (mavidos): A multicentre, double-blind, randomised placebo-controlled trial. Lancet Diabetes Endocrinol. 2016, 4, 393-402. [CrossRef]

41. Sluyter, J.D.; Camargo, C.A., Jr.; Stewart, A.W.; Waayer, D.; Lawes, C.M.M.; Toop, L.; Khaw, K.T.; Thom, S.A.M.; Hametner, B.; Wassertheurer, S.; et al. Effect of monthly, high-dose, long-term vitamin D supplementation on central blood pressure parameters: A randomized controlled trial substudy. J. Am. Heart Associ. 2017, 6. [CrossRef] [PubMed]

42. Sluyter, J.D.; Camargo, C.A.; Waayer, D.; Lawes, C.M.M.; Toop, L.; Khaw, K.T.; Scragg, R. Effect of monthly, high-dose, long-term vitamin D on lung function: A randomized controlled trial. Nutrients 2017, 9. [CrossRef] [PubMed]

43. Cazzola, M.; MacNee, W.; Martinez, F.J.; Rabe, K.F.; Franciosi, L.G.; Barnes, P.J.; Brusasco, V.; Burge, P.S.; Calverley, P.M.; Celli, B.R.; et al. Outcomes for COPD pharmacological trials: From lung function to biomarkers. Eur. Respir. J. 2008, 31, 416-469. [CrossRef] [PubMed]

44. Zhao, L.J.; Zhou, Y.; Bu, F.; Travers-Gustafson, D.; Ye, A.; Xu, X.; Hamm, L.; Gorsage, D.M.; Fang, X.; Deng, H.W.; et al. Factors predicting vitamin D response variation in non-Hispanic white postmenopausal women. J. Clin. Endocrinol. Metab. 2012, 97, 2699-2705. [CrossRef] [PubMed]

45. Didriksen, A.; Grimnes, G.; Hutchinson, M.S.; Kjaergaard, M.; Svartberg, J.; Joakimsen, R.M.; Jorde, R. The serum 25-hydroxyvitamin D response to vitamin d supplementation is related to genetic factors, BMI, and baseline levels. Eur. J. Endocrinol. 2013, 169, 559-567. [CrossRef] [PubMed]

46. Hansen, K.E.; Johnson, R.E.; Chambers, K.R.; Johnson, M.G.; Lemon, C.C.; Vo, T.N.; Marvdashti, S. Treatment of vitamin D insufficiency in postmenopausal women: A randomized clinical trial. JAMA Intern. Med. 2015, 175, 1612-1621. [CrossRef] [PubMed]

47. Scragg, R.; Stewart, A.W.; Waayer, D.; Lawes, C.M.M.; Toop, L.; Sluyter, J.; Murphy, J.; Khaw, K.T.; Camargo, C.A., Jr. Effect of monthly high-dose vitamin D supplementation on cardiovascular disease in the Vitamin D Assessment study: A randomized clinical trial. JAMA Cardiol 2017, 2, 608-616. [CrossRef] [PubMed] 
48. Khaw, K.T.; Stewart, A.W.; Waayer, D.; Lawes, C.M.M.; Toop, L.; Camargo, C.A., Jr.; Scragg, R. Effect of monthly high-dose vitamin D supplementation on falls and non-vertebral fractures: Secondary and post-hoc outcomes from the randomised, double-blind, placebo-controlled ViDA trial. Lancet Diabetes Endocrinol. 2017, 5, 438-447. [CrossRef]

49. Hollis, B.W.; Wagner, C.L. Clinical review: The role of the parent compound vitamin D with respect to metabolism and function: Why clinical dose intervals can affect clinical outcomes. J. Clin. Endocrinol. Metab. 2013, 98, 4619-4628. [CrossRef] [PubMed]

50. Jorde, R.; Grimnes, G. Serum cholecalciferol may be a better marker of vitamin D status than 25-hydroxyvitamin D. Med. Hypotheses 2018, 111, 61-65. [CrossRef] [PubMed]

51. Rose, G. Sick individuals and sick populations. Int. J. Epidemiol. 1985, 14, 32-38. [CrossRef] [PubMed]

52. Nessvi, S.; Johansson, L.; Jopson, J.; Stewart, A.; Reeder, A.; McKenzie, R.; Scragg, R.K. Association of 25-hydroxyvitamin D3 levels in adult new zealanders with ethnicity, skin color and self-reported skin sensitivity to sun exposure. Photochem. Photobiol. 2011, 87, 1173-1178. [CrossRef] [PubMed]

53. Malihi, Z.; Wu, Z.; Stewart, A.W.; Lawes, C.M.; Scragg, R. Hypercalcemia, hypercalciuria, and kidney stones in long-term studies of vitamin D supplementation: A systematic review and meta-analysis. Am. J. Clin. Nutr. 2016, 104, 1039-1051. [CrossRef] [PubMed]

54. Malihi, Z.; Wu, Z.; Mm Lawes, C.; Scragg, R. Noncalcemic adverse effects and withdrawals in randomized controlled trials of long-term vitamin D2 or D3 supplementation: A systematic review and meta-analysis. Nutr. Rev. 2017, 75, 1007-1034. [CrossRef] [PubMed]

55. Kiely, M.; Black, L.J. Dietary strategies to maintain adequacy of circulating 25-hydroxyvitamin D concentrations. Scand. J. Clin. Lab. Investig. Suppl. 2012, 243, 14-23.

56. Cashman, K.D.; Ritz, C.; Kiely, M.; Odin, C. Improved dietary guidelines for vitamin D: Application of individual participant data (IPD)-level meta-regression analyses. Nutrients 2017, 9. [CrossRef] [PubMed]

57. Institute of Medicine, Food and Nutrition Board, Committee to Review Dietary Reference Intakes for Vitamin D and Calcium. Dietary Reference Intakes for Calcium and Vitamin D; Institute of Medicine: Washington, DC, USA, 2011. 